\begin{tabular}{|c|c|c|}
\hline $\begin{array}{l}\text { KULTURA } \\
\text { I } \\
\text { SPOLECZENS }\end{array}$ & $\begin{array}{l}\text { POLSKA AKADEMIA NAUK } \\
\text { KOMITET SOCJOLOGII } \\
\text { INSTYTUT STUDIÓW POLITYCZNYCH } \\
2015, \mathrm{nr} 4\end{array}$ & ISSN 0023-5172 \\
\hline
\end{tabular}

KRZYSZTOF JASIECKI

Instytut Filozofii i Socjologii PAN

\title{
DLACZEGO WARTO CZYTAĆ SUN YAT-SENA? POŻYTKI Z LEKTURY PRAC „DUCHOWEGO OJCA” NOWOŻYTNYCH CHIN
}

W lipcu 2004 roku w Pekinie odbył się 36. Światowy Kongres International Institute of Sociology, który pracował pod hasłem „Social Change in the Age of Globalization". Immanuel Wallerstein (2004, s. 5) jako członek komitetu honorowego Kongresu podkreślał wówczas, że organizacja takiego spotkania w Chinach stanowi przejaw internacjonalizacji socjologii i nauk społecznych obejmującej także państwo stanowiące dużą część świata, a także wyróżniające się bardzo długą tradycją kulturową, która jest niedostatecznie reprezentowana w światowej produkcji wiedzy. Trafność tego spostrzeżenia dotyczy również koncepcji liderów politycznych kraju aspirującego do roli największej gospodarki świata ${ }^{1}$. Na tym tle warto zwrócić uwagę na publikację głównej pracy jednego $z$ najwybitniejszych przywódców Chin w XX wieku Sun Yat-sena (1866-1925), twórcy i lidera rewolucyjnej partii narodowej Kuomintang (KMT), inspiratora abdykacji małoletniego cesarza Puyi, proklamowania Republiki Chińskiej oraz jej pierwszego, tymczasowego prezydenta powołanego w końcu 1912 roku$^{2}$.

Adres do korespondencji: kjasieck@ifispan.waw.pl

${ }^{1}$ Zgodnie z prognozami Goldman Sachs i „The Economist” realizacja takich aspiracji staje się możliwa, według różnych szacunków, w perspektywie najbliższych kilku lub kilkunastu lat (O’Neil 2013, s. 101).

2 Zob. wspomnienia cesarza Puyi (1988) oraz autobiograficzną sagę rodzinną osadzoną w realiach schyłku cesarstwa chińskiego, w okresie japońskiej okupacji, poprzez rządy Mao i Rewolucję Kulturalną do stłumienia protestów studenckich w 1989 roku (Chang 2003). Ten bardzo burzliwy okres w historii Chin przybliża także film biograficzny Bernardo Bertolucciego Ostatni cesarz z 1987 roku. 
Koncepcje polityczne Suna ukształtowały sposób myślenia dużej części chińskich elit o modernizacji państwa i jego miejscu we współczesnym świecie. $\mathrm{Na}$ prace Suna powołują się zarówno przywódcy partii komunistycznej w Pekinie, jak i liderzy KMT, którzy po przegranej wojnie domowej utworzyli niepodległe państwo na Tajwanie, chociaż kierujący nim generał Chiang Kai-shek wprowadził tradycjonalistyczny, autorytarny ustrój polityczny wspierany przez Stany Zjednoczone. Sun jest uznawany za twórcę nowoczesnych Chin, a jego idee nadal stanowią układ odniesienia w dyskusjach o rozwoju kraju. Przejawem tego zjawiska stało się między innymi nawiązanie do koncepcji Suna przez Deng Xiaopinga w programie reform zainicjowanych w 1978 roku. Został on wymieniany w preambule do konstytucji Chińskiej Republiki Ludowej (ChRL) i jest honorowany na Tajwanie jako założyciel Republiki Chińskiej ${ }^{3}$, a do mauzoleum Sun Yat-sena w Nankinie każdego roku przybywa tysiące Chińczyków $z$ całego świata ${ }^{4}$.

Przedstawiana tu edycja jednego z najważniejszych traktatów politycznych w historii tego kraju, zbioru Trzy zasady ludu (2014), jest pierwszym polskim przekładem z języka chińskiego zapisu cyklu publicznych wykładów Suna wygłoszonych na uniwersytecie w Kantonie między styczniem i sierpniem 1924 roku. Wyznaczyły one nowe strategiczne cele chińskich elit, co powoduje, że praca jest istotna dla wszystkich, którzy chcą rozumieć współczesną politykę Państwa Środka z uwzględnieniem jej historycznych uwarunkowań. Książka prezentuje autorską wizję modernizacji Chin i odbudowy ich mocarstwowej pozycji jako kraju demokratycznego, kierującego się konfucjańskimi ideami moralnymi. Jej polską wersję (zawierającą pewne skróty, największe w części „zasady dobrobytu ludu”) opracowali naukowo Krzysztof Gawlikowski i Małgorzata Ławacz z Centrum Cywilizacji Azji Wschodniej Szkoły Wyższej Psychologii Społecznej w Warszawie. Tłumaczenie Agnieszki Łobacz powstało na podstawie pekińskich i tajwańskich wydań dzieł Suna (szerzej Sun Yat-sen 20145).

Liczącą 286 stron pracę otwiera wprowadzenie, na które składają się cztery artykuły redaktorów tomu o łącznej objętości 64 stron, które przybliżają czytelnikom postać Sun Yat-sena, jego życie, działalność i rolę w historii Chin, ze szczególnym uwzględnieniem znaczenia rewolucji republikańskiej z 1911 roku, a także porównują ją z rewolucją francuską 1798 roku. W tej części znajduje się również charakterystyka głównych kontrowersji wokół koncepcji Suna oraz jej

\footnotetext{
3 Szerzej zob. pierwszą polską biografię Sun Yat-sena (Góralczyk 2013).

4 Szczególny status dziedzictwa Suna obrazują również losy bardzo wpływowych sióstr Song. Starsza z nich Qingling była drugą żoną Sun Yat-sena. Związała się z KPCh, a w ChRL jako nominalny przywódca Rewolucyjnego Kuomintangu (jednej z partii wspierającej rządy komunistyczne) zajmowała stanowisko wiceprezydenta. Z kolei młodsza siostra Meiling od 1927 roku była żoną i osobistym sekretarzem Czang Kaj-szeka, w okresie drugiej wojny światowej odgrywała ważną rolę w pozyskiwaniu wsparcia Stanów Zjednoczonych dla KMT, a później dla rządu na Tajwanie, jak również w polityce wewnętrznej.

${ }^{5}$ Dalej powołując się na to wydanie podaję w tekście numer strony.
} 
różnych interpretacji i współczesnego zastosowania. O najważniejszym z nich Krzysztof Gawlikowski pisze: „Gdy reżim maoistowski zaczął się załamywać, a w kraju pogłębiał się chaos, można było sięgnąć do alternatywnego "programu narodowego" Suna, osadzonego w realiach chińskich" (s. 64). W takim kontekście wskazywane są między innymi idee modernizacji Chin łączącej zachodnie doktryny z tradycjami konfucjanizmu, nowoczesny patriotyzm, budowa silnej pozycji międzynarodowej („odrodzenie Chin”, „zbieranie ziem chińskich"), strategia rozwoju gospodarczego wyróżniająca się rozbudowanym interwencjonizmem państwowym wspierającym industrializację i inwestycje $\mathrm{w}$ infrastrukturę lub stopniowa demokratyzacja systemu autorytarnego poprzez wprowadzanie instytucji demokracji lokalnej.

Na podkreślenie zasługuje opatrzenie książki przez redaktorów naukowych obszernymi wyjaśnieniami językowymi, terminologicznymi i historycznymi, które są bardzo istotne dla polskiego odbiorcy, nie zawsze dobrze zorientowanego w niuansach dziejów oraz myśli politycznej Państwa Środka. Ich zamieszczenie ułatwia pełniejsze zrozumienie tekstu zarówno w kontekście warunków chińskich, jak i państw zachodnich. Takie opracowanie publikacji (w ostatnich latach stające się rzadkością ze względu na motywowane obniżaniem kosztów obniżanie standardów edytorskich) przypomina znakomitą serię Biblioteki Narodowej im. Ossolińskich z typowym dla jej wydawnictw krytycznym wstępem, odniesieniami do literatury krajowej i zagranicznej wraz z erudycyjnymi przypisami.

Tytułowe trzy zasady ludu charakteryzowane przez Sun Yat-sena to zasada narodowa, zasada władzy ludu oraz zasada dobrobytu ludu. Kolejność zasad oddaje hierarchię ich znaczenia $\mathrm{w}$ porządku politycznym, zakorzenioną $\mathrm{w}$ chińskiej filozofii i kulturze, które są odmienne od dominujących w państwach zachodnich. Warto o tym pamiętać zwłaszcza dzisiaj, w warunkach kryzysu i kwestionowania globalizacji w stylu anglosaskim, o której John Gray, liberalny konserwatysta $z$ London School of Economics pisał, że jest prawdopodobnie ostatnią formą oświeceniowego projektu cywilizacji uniwersalnej. Jednak „wyłonienie się prawdziwie światowej gospodarki nie oznacza globalizacji zachodnich wartości i instytucji” (Gray 2001, s. 425). Chiny są modelowym przykładem ograniczeń uniwersalnych roszczeń neoliberalnej globalizacji. Książka Suna przybliża przesłanki chińskiej odrębności w sferze świadomości historycznej, interpretacji zjawisk politycznych i przekonania o wysokim poziomie rodzimej kultury przewyższającej zachodnich „barbarzyńców” ${ }^{6}$, między innymi

\footnotetext{
${ }^{6}$ Chińczycy tradycyjnie uważali, że są jedynymi cywilizowanymi ludźmi na świecie, co uzasadniała potęga Państwa Środka, które przez stulecia nie miało w Azji Wschodniej żadnej przeciwwagi politycznej, gospodarczej lub kulturowej. Sinocentryczny charakter tego regionu znajdował wyraz w rozpowszechnieniu alfabetu z chińskimi znakami, konfucjanizmu i buddyzmu oraz chińskiego systemu prawnego (Lee 2011, s. 87-92). Poglądy wobec „barbarzyńców” zaczęły się zmieniać w XIX wieku, gdy ekspansja mocarstw europejskich ujawniła słabość Chin. Po 1895 roku uka-
} 
w zakresie filozofii politycznej, pokojowych metod prowadzenia polityki, akceptacji tradycji konfucjańskich (w tym szacunku dla władzy i hierarchii) czy szczególnej roli rodziny.

Część dotycząca „zasady narodowej” skupia się na definiowaniu narodu w kategoriach wspólnoty etniczno-kulturowej spajanej więzami krwi. Taka definicja, inspirowana teoriami zachodnimi, wychodziła poza utrwalone chińskie skojarzenia, związane głównie z tożsamością pokrewieństwa, rodziny i klanu, tradycji kulturowej, a niekiedy również z miejscem zamieszkania (wspólnoty wiejskie, prowincje). Sprzyjała tworzeniu republikańskiej, nowoczesnej wersji identyfikacji wspólnotowych, przełamującej brak narodowej solidarności wyrażany w powiedzeniu, że „Chińczycy są jak góra sypkiego piasku” (s. 70). Sun głosił potrzebę łączenia nacjonalizmu etnicznego $z$ nacjonalizmem państwowym. Wśród czynników sprzyjających powstawaniu narodu wymieniał więzy krwi, sposób bytowania, język, religię, obyczaje i nawyki oraz głoszenie patriotyzmu w zachodnim sensie, otwartego na współpracę z innymi.

Rozróżniał naród i państwo. W interpretacji ich genezy posługiwał się wprowadzonym przez starożytnego filozofa chińskiego Mencjusza (371-289 p.n.e.) rozróżnieniem dwóch metod rządzenia: Drogi Królewskiej i Drogi Hegemona. Droga Królewska odwołuje się do rządów opartych na cnocie, wpajających zasady moralne oraz normy przyzwoitości, unikających użycia przymusu, kar i przemocy. Jej zasady mają sprzyjać formowaniu się narodu w sposób naturalny. Natomiast Droga Hegemona posługuje się siłami zbrojnymi, przemocą i surowymi karami, które w ten sposób tworzą wspólnotę państwową. Drogę Hegemona przypisywał mocarstwom zachodnim, a Drogę Królewską uważał za ideał postulowany dla Chin, które miałyby odgrywać rolę światowego „przywódcy moralnego". W tym zakresie inspiracją są tradycje podporządkowywania sobie słabszych lub mniejszych narodów metodami pokojowymi, stosowania polityki „uspokajania świata”.

Poglądy Suna dotyczące stosunków międzynarodowych wpisują się w dominujący ówcześnie paradygmat realistyczny (często interpretowany neodarwinistycznie), koncentrujący się na interesach państw walczących $z$ innymi krajami o władzę. Jako wzorzec do naśladowania traktował on Japonię, która dzięki reformom Meiji rozpoczętym w 1868 roku przeprowadziła skuteczną modernizację kraju i otworzyła się na wpływy Zachodu ${ }^{7}$. W okresie kilku-

zały się pierwsze chińskie tłumaczenia zachodnich prac filozoficznych, socjologicznych i ekonomicznych. W 1915 roku na uniwersytecie pekińskim została utworzona pierwsza katedra filozofii zachodniej w Chinach (w jego strukturze istniały także katedry filozofii chińskiej i hinduskiej), a w latach 1919-1920 John Dewey i Bertrand Russell byli pierwszymi zachodnimi filozofami wykładającymi w tym kraju (Yu-Lan 1991, s. 552-553).

${ }^{7}$ Sun Yat-sen pobierał nauki na Hawajach w szkole brytyjskich metodystów, a także w Hongkongu w dwóch szkołach misyjnych. Przyjął chrzest w obrządku protestanckim (baptyzm) oraz przez dziesięć lat przebywał w Japonii, Europie i Stanach Zjednoczonych. Deng Xiaoping również przez część życia pracował i studiował zagranicą, najpierw w Paryżu, a później w Moskwie. 
dziesięciu lat taka polityka umożliwiła Japonii (nazywanej wtedy w Chinach „Anglią Wschodu”) osiągnięcie pozycji największej potęgi Azji, porównywalnej do mocarstw zachodnich. Nowego znaczenia w warunkach globalizacji nabierają uwagi Suna dotyczące roli potencjału demograficznego państw świata, jak również sinocentryczny sposób widzenia stosunków międzynarodowych, zakorzeniony w tradycji Państwa Środka, którego dominację potwierdzały w przeszłości wszystkie kraje Azji Wschodniej składając hołd i trybut. Sun krytykował zawłaszczenie „wszelkich spraw świata” przez Europę i Amerykę, przypominając mocarstwowość Chin, w tym dawny wasalny status Wietnamu, Korei i Birmy, przynależność do Chin Mongolii, Tajwanu, Tybetu, Hongkongu i wysp peskadorskich na Morzu Południowochińskim; przysyłających trybut na dwór chiński wysp Riukiu, Celebes, Borneo, Sumatry, Jawy, Cejlonu, Bhutanu, zależnych od Chin państw Azji Środkowej (jak chanat Kokandu) oraz ziem na północ od Amuru, które przejęła Rosja ${ }^{8}$. Chiny, które do 1820 roku były największą gospodarką świata, w XIX wieku przeżywały dramatyczny upadek, stając się półkolonią podporządkowaną interesom Wielkiej Brytanii, Francji, Rosji, Niemiec i Stanów Zjednoczonych. Sun określał Chiny tamtego czasu jako „kolonię wielu państw", które narzuciły im niekorzystne traktaty - reperacje wojenne, politykę monetarną, dominację zagranicznych instytucji finansowych, kontrolę nad systemem celnym, przejmowanie własności, wymuszanie importu towarów, opłat przewozowych, koncesji terytorialnych i handlowych dla cudzoziemców.

Interesujące są poglądy autora Trzech zasad ludu dotyczące funkcji rozmaitych ideologii, w tym nacjonalizmu, imperializmu czy kosmopolityzmu. Nawiązują one wyraźnie do tradycji pragmatyzmu i świadomości zmienności roli ideologii w różnych okresach historii. „Nie można mówić ogólnie, że dana ideologia jest dobra lub niedobra, należy spojrzeć, czy nam ona służy, czy nie. Jeśli nam służy, to jest dobra, a jeśli nam nie służy — jest niedobra” (s. 118). Jako przykład przywołuje ideologię kosmopolityzmu z okresu wielkości Chin, która była użyteczna, bo kraj ten „chciał być panem całego świata” i „by świat za nimi podążał". Służyło to wtedy ich interesom, a inne państwa posługiwały się odmiennymi ideologiami. Ich przejawem były nacjonalizm i imperializm (określany przez Chińczyków jako „strategia panowania $z$ daleka”), będące w pewnym okresie użytecznymi instrumentami polityki mocarstw europejskich legitymizujących ich agresję i ekspansywność terytorialną w różnych regionach

8 Gdy przebywałem w Szanghaju w 1992 roku, naukowcy z Chińskiej Akademii Nauk Społecznych pokazywali mi mapy dawnych Chin, a „zbieranie ziem chińskich” wiązali z uzgodnionym już wtedy z Wielką Brytanią i Portugalią powrotem do macierzy Hongkongu i Makau, a w przyszłości także z integracją Tajwanu, co przy zastosowaniu polityki ,jedno państwo - dwa ustroje” miało nastąpić przed rokiem 2020. W Federacji Rosyjskiej od lat dyskutowany jest problem narastającego osadnictwa chińskiego na terenach, które niegdyś należały do Państwa Srodka, wraz z konsekwencjami tej tendencji, między innymi w postaci możliwości zakwestionowania przynależności do Rosji obszarów zdominowanych przez przybyszów z Chin. 
świata. Analogiczną rolę pełniły później nowe wersje kosmopolityzmu, którego najbardziej znaczące odmiany tworzyły po pierwszej wojnie światowej liberalna Wielka Brytania i bolszewicka Rosja.

W takim kontekście Sun podkreślał konieczność wzmacniania „poczucia narodowego" bez którego Chińczycy byliby zbyt słabi w konfrontacji z nacjonalizmami ówczesnych potęg i nowymi ideologiami kosmopolitycznymi. Niektóre $z$ takich ideologii uważał za korzystne dla Chin, jak w przypadku internacjonalizmu Rosji bolszewickiej występującej przeciwko zachodnim mocarstwom $\mathrm{w}$ imię rewolucyjnych postulatów politycznych - wprowadzenia ustroju komunistycznego, zmian w międzynarodowym układzie sił lub zasady samostanowienia narodów. Bolszewicy i międzynarodowy ruch komunistyczny były w ostatnim okresie jego życia jedynymi znaczącymi sojusznikami republikańskich Chin. Równocześnie jednak, chociaż wszedł w sojusz z utworzoną w 1921 roku Komunistyczną Partią Chin (KPCh), Sun występował przeciwko Ruchowi Nowej Kultury odrzucającemu klasyczną kulturę chińską z konfucjanizmem na czele, propagującemu stworzenie nowego społeczeństwa inspirowanego zachodnimi wzorcami. Rozpatrywał bowiem patriotyzm bazujący na tradycyjnych wartościach kultury chińskiej jako kluczowy kapitał polityczny. Pisał: „jeśli w przyszłości chcemy być zdolni do rządzenia krajem [...] musimy najpierw odbudować patriotyzm i pozycję naszego kraju" (s. 174).

Część druga, „zasady władzy ludu”, dotyczy kształtu instytucji politycznych republiki. Sun Yat-sen wyrażał pogląd, że powinny one wykorzystywać historię demokracji zachodniej jako materiał do dyskusji, który jednak dla Chin nie jest wzorem do naśladowania. Przedstawił i rozwijał koncepcję specyficznej metody wprowadzania nowego ustroju wynikającej z lokalnych uwarunkowań, jak również docelowej odrębności chińskiego modelu demokracji. Przejawem takiego podejścia była koncepcja budowy republiki w trzech fazach: rządów wojskowych (które miały trwać trzy lata lub mniej), budowy lokalnego samorządu terytorialnego (około sześciu lat) oraz wyłonienia w wyborach powszechnych konstytucyjnych organów państwa. Sun przedstawił program struktury politycznej państwa oparty na koncepcji „konstytucji pięciu władz”. Typowy dla zachodniego konstytucjonalizmu podział władzy na władzę ustawodawczą, wykonawczą i sądowniczą miało korygować wyodrębnienie władzy egzaminacyjnej (odwołującej się do tradycji mandarynatu w tworzeniu nowoczesnej służby cywilnej) i władzy kontrolnej, która miała przejąć funkcje tzw. cenzoratu z okresu cesarstwa ${ }^{9}$. Postulował wprowadzenie narodowej kontroli nad rządem poprzez prawo wyborcze, prawo odwołania, prawo inicjatywy ustawodawczej i prawo do referendum.

\footnotetext{
${ }^{9}$ Zdaniem Suna w dawnych Chinach cesarz skupiał w swoim ręku władzę sądowniczą, ustawodawczą i wykonawczą, natomiast władza kontrolna i egzaminacyjna były niezależne, co nie miało odpowiednika $\mathrm{w}$ państwach zachodnich. Na temat zastosowań jego koncepcji w praktyce chińskiego konstytucjonalizmu zob. Rowiński, Jakubiec 2006.
} 
Na podstawie analizy ustrojów politycznych głównych krajów europejskich i Stanów Zjednoczonych Sun twierdził, że zachodnie idee wolności, demokracji i równości nie są odpowiednie dla społeczeństwa chińskiego. W takiej interpretacji słabe rządy cesarskie i kontrola jednostki przede wszystkim ze strony rodziny, rodu i wspólnoty lokalnej powodowały, że Chińczycy nie doświadczali bezpośredniego ucisku ze strony władców absolutnych, który do niedawna dominował w większości państw europejskich. Wolność jednostki $\mathrm{w}$ relacjach $\mathrm{z}$ państwem nie była zatem $\mathrm{w}$ Chinach problemem, zwłaszcza że nie znali oni nawet takiego pojęcia, analogicznie jak terminu „demokracja”. Pojęcia te dotarły do Chin z Zachodu. Także trwały podział na bogatych i biednych w Chinach wydawał się wątpliwy, gdyż - jak uważał Sun — w tym kraju są jedynie biedni i jeszcze biedniejsi ( $z$ wyjątkiem garstki wielkich posiadaczy ziemskich i właścicieli dużego kapitału). Dziedziczenie dotyczyło tylko cesarza, a inne pozycje w hierarchii stratyfikacyjnej mogły być przechodnie, co umożliwiało awans na wysokie stanowiska w państwie ludzi z niższych warstw społecznych i osłabiało występowanie trwałych nierówności w porównaniu ze społeczeństwami zachodnimi ${ }^{10}$.

W efekcie polityczne cele rewolucji chińskiej Sun definiował jako przeciwne do celów rewolucji europejskiej. „Europa potrzebowała rewolucji, bo dawniej miała zbyt mało wolności, musiała więc o nią walczyć. My mamy wolności zbyt wiele, ale nie mamy struktur instytucjonalnych" (s. 206). Dodaje też w innym miejscu: „Jednostka nie może mieć nadmiernej wolności, pełną wolność powinno mieć państwo. Kiedy państwo będzie miało wolność działania, Chiny staną się potężne" (s. 208). Zwracał uwagę na zróżnicowania ustrojowe współczesnego świata i występujące w państwach zachodnich kontrowersje wokół sposobów definiowania i rozwijania demokracji, zakresu praw wyborczych, ograniczeń parlamentaryzmu, charakteru organizacji władzy w państwie (unitarnej, federalnej, zdecentralizowanej itd.), podziałów klasowych, organizacji robotniczych, rasizmu i pozostałości niewolnictwa, praw kobiet, podziału na monarchie i republiki, specyfikę demokracji Szwajcarii oraz nowe idee polityczne wprowadzane przez bolszewików w Rosji. Sun uważał, że propagowane przez niego zasady władzy ludu mogą uczynić Chiny państwem, „które jako pierwsze na kuli ziemskiej zapoczątkuje tworzenie nowego świata" (s. 273).

Część trzecia, „zasada dobrobytu ludu”, została przetłumaczona w niewielkim fragmencie, liczącym dwanaście stron. Wybór ten jest konsekwencją ograniczeń finansowych redaktorów tomu, jak również ich przekonania, że ta część

\footnotetext{
10 Na przykład zdaniem niektórych badaczy w epoce Han więcej było kanclerzy, którzy awansowali z chłopskiej rodziny na najwyższy urząd, niż w Stanach Zjednoczonych prezydentów, którzy wywodzili się z niezamożnych rodzin (Gawlikowski 2012, s. 30). Jednak kwestionowanie trwałości podziałów społecznych w Chinach jako uzasadnienie dla odrzucania zachodnich idei wolności, demokracji oraz równości, podobnie jak idealizowanie przywództwa moralnego, mandarynatu i koncepcji „konstytucji pięciu władz”, nie tyle charakteryzowało przeszłość, ile raczej dostarczało Sunowi argumentacji uzasadniającej odmienność celów, metod i instytucji rewolucji chińskiej.
} 
pracy stosunkowo najbardziej się „zestarzała”. Dotyczy bowiem szczegółowych kwestii rekonstrukcji chińskiej gospodarki, reformy rolnej i własności ziemi, rozwoju przemysłu, stosunków pracy i innych zagadnień, które ze względu na upływ czasu radykalnie zmieniły charakter. W tej części na uwagę zasługuje stosunek do socjalizmu, komunizmu i marksizmu oraz poglądy dotyczące roli państwa w gospodarce. Sun wyjaśniając zasadę dobrobytu ludu odwołuje się do starego chińskiego słowa minsheng. Posługuje się nim dla odróżnienia od terminu „socjalizm”, który po pierwszej wojnie światowej nabrał wielu znaczeń, w tym konkurencyjnych politycznie, uosobianych przez partie socjaldemokratyczne, komunistyczne i narodowosocjalistyczne. Stwierdza, że celem zasady dobrobytu ludu jest doprowadzenie do wyrównywania zasobów finansowych społeczeństwa i umożliwienie wspólnego posiadania. Dystansuje się deklaratywnie i niekonsekwentnie od socjalizmu oraz komunizmu, chociaż w zasadniczych wymiarach jest bliski ich perspektywie ideologicznej i programowej (między innymi w zakresie roli państwa w gospodarce, własności, egalitaryzmu lub podporządkowania jednostki państwu).

Sun cenił Marksa jako najbardziej wnikliwego badacza problemów socjalnych po rewolucji przemysłowej, lecz uważał, że opierał się on na faktach z minionych czasów, nie znajdujących potwierdzenia w późniejszym rozwoju społeczeństw lub uogólnieniach mało użytecznych w warunkach Chin. Na przykład, jego zdaniem, na Zachodzie wzrost roli państwa w zakresie edukacji oraz warunków pracy osłabiał konflikt interesów między kapitalistami i robotnikami, co wraz z rozwojem spółdzielni konsumenckich, nałożeniem na kapitalistów wyższych podatków i podatku od dziedziczenia zmniejszało rolę walki klas jako mechanizmu postępu społecznego. Równocześnie podkreślał, że podobnie jak w Rosji, przeprowadzenie rewolucyjnych zmian społecznych w Chinach wiąże się $z$ realizacją innych celów niż w rozwiniętych krajach zachodnich. Przejawem chińskiej specyfiki było głoszenie dwóch zasad: równego prawa własności ziemi i umiarkowanego posługiwania się kapitałem. W takiej interpretacji „zasada dobrobytu ludu to socjalizm, a także komunizm, lecz każda z tych idei posługuje się innymi metodami" (s. 283).

Sun postulował politykę gospodarczą zbliżoną do realizowanej przez Lenina w Rosji w okresie komunizmu wojennego polityki „kapitalizmu państwowego". Powoływał się jednak w tym zakresie na kraje zachodnie, które podczas pierwszej wojny światowej nacjonalizowały koleje, statki i duże fabryki (s. 277). Wśród proponowanych środków wskazywał między innymi ograniczenie roli prywatnego kapitału, tworzenie kapitału państwowego i przedsiębiorstw państwowych, uspołecznienie dystrybucji ograniczające nierówności podziału dóbr, przejęcie przez państwo środków transportu, komunikacji i łączności; publiczne inwestycje w zasoby kopalin, rozbudowę infrastruktury komunikacyjnej, regulowanie obrotu gruntami przeciwdziałające spekulacji czy ograniczenie importu z zagranicy uzasadniane argumentacją "tracenia prawa do zysków”. Poglądy gospodarcze Suna można interpretować jako połączenie 
chińskiego socjalizmu agrarnego (równe prawa własności ziemi) z rozbudowanym interwencjonizmem państwowym ograniczającym rolę prywatnej własności. Są też one naznaczone wpływami wsparcia zbrojnego i finansowego ZSRR dla sojuszu KMT oraz KPCh, co w przyszłości miało umożliwić bolszewikom kontrolę nad Chinami ${ }^{11}$. Chociaż poglądy te mają $\mathrm{w}$ pewnej mierze charakter utopijny, jak zasada równych praw własności ziemi, lub przeszły negatywnie test efektywności (np. ograniczanie roli kapitału prywatnego), to trzeba zauważyć, że etatystyczne i antyliberalne koncepcje gospodarcze $\mathrm{w}$ tamtym okresie były wpływowe również na Zachodzie. Widziano w nich alternatywę wobec orientacji na „wolny handel” i „gospodarkę rynku światowego”, która w wielu krajach prowadziła do głębokich kryzysów strukturalnych, także w sferze politycznej. Najbardziej znaczącymi przejawami takiego podejścia było: przejęcie władzy we Włoszech przez Benito Mussoliniego w 1922 roku i wprowadzenie założeń faszyzmu oraz rozwój Narodowosocjalistycznej Niemieckiej Partii Robotniczej (NSDAP), w tym publikacja książki Adolfa Hitlera Mein Kampf (1925). Różne odmiany rządów prawicowych, autorytarnych i etatystycznych szybko zdominowały większą część Europy, zwłaszcza powstałe po pierwszej wojnie światowej nowe państwa Europy Środkowej i Wschodniej, od 1926 roku z Polską włącznie.

Dziedzictwo Sun Yat-sena, tak jak w przypadku innych wybitnych przywódców politycznych, jest przedmiotem wielu interpretacji. Ich specyfikę określa wyjątkowe miejsce Suna jako niekwestionowanego autorytetu zarówno w rządzonej przez partię komunistyczną ChRL, jak i na Tajwanie. Gdyby szukać dla tej postaci odpowiednika w historii Polski, to chyba najbliższe mogłoby być skojarzenie kumulowania w jednej osobie myśli politycznej Romana Dmowskiego jako twórcy nowoczesnego ruchu narodowego i Józefa Piłsudskiego, łączącego (do pewnego okresu) tradycje patriotyzmu z etosem socjalistycznym. Takie podejście pobudza do myślenia w kategoriach porównawczych i stawiania pytań $\mathrm{w}$ rodzaju: Jak rosnące aspiracje narodowe i polityczne widziano w Polsce i w Chinach? Jak definiowano istniejący stan rzeczy i przyszłe rozwiązania ustrojowe? Jaka była w tym zakresie rola doświadczeń historycznych oraz „lokalnej” kultury politycznej? Książkę Suna można rozpatrywać jako chińskie spojrzenie na kluczowe problemy polityczne tamtej epoki. Przybliża ona dobrze przesłanki specyficznej świadomości historycznej i interpretacji polityki w kate-

11 Przywódcy bolszewiccy wsparli Suna z intencją przyspieszenia zjednoczenia Chin i utworzenia silnego rządu centralnego. Dzięki temu powstał tymczasowy sojusz KMT i KPCh. Rosyjscy doradcy przygotowali nowy, oparty na leninowskim modelu partii statut KMT, który zaaprobował Sun. W ramach współpracy międzypartyjnej do KMT mogli wstępować indywidualnie działacze komunistyczni. Jednym z nich był Mao Zedong, który jako członek KC KPCh został delegatem na pierwszy zjazd KMT w styczniu 1924 roku i wszedł do sekcji wykonawczej tej partii w Szanghaju. Na czele Akademii Wojskowej w Huangpu, utworzonej przez KMT na wzór szkolnictwa Armii Czerwonej, stanął Chiang Kai-Shek (Legrand i in. 2000, s. 28-30). Funkcjonowanie KMT jako partii typu leninowskiego na Tajwanie analizuje Chan (1996). 
goriach przekonania o wyjątkowej wartości kultury chińskiej wraz z jej utrwalonymi przez tysiąclecia sposobami odgrywania roli światowego przywódcy. Odbudowa takiej roli stała się strategicznym celem chińskich elit w kolejnych dziesięcioleciach. Lektura Suna sprzyja również rozpatrywaniu ówczesnych warunków jako inspiracji do współczesnej refleksji. Jak przetworzyć słabe rodzime kapitały na sukces polityczny i gospodarczy $\mathrm{w}$ relacjach $\mathrm{z}$ silniejszymi aktorami stosunków międzynarodowych? Jak budować mocniejszą pozycję państwa i społeczeństwa, by wyjść z roli peryferii centrów współczesnego świata?

Jednej z odpowiedzi na takie pytanie dostarcza pragmatyzm Suna w podejściu do ideologii i polityki gospodarczej. Znalazł on kontynuację w słynnym powiedzeniu Deng Xiaopinga: „Nieważne, czy kot jest biały czy czarny, byleby łapał myszy”, akcentującym potrzebę elastycznego podejścia do gospodarki, korzystającego umiejętnie $z$ rozmaitych recept ekonomicznych ${ }^{12}$. Na rzecz takiej metody działa przeświadczenie, że także współcześnie pojawiają się nowe ideologie, które (jak wskazywany niegdyś przez Suna imperializm lub kosmopolityzm) promują systemy instytucjonalne sprzyjające asymetrycznej dystrybucji władzy i bogactwa, nie służącej dobrze rozwojowi Chin ${ }^{13}$. W ostatnich dekadach ich najbardziej wpływową wersją stała się neoliberalna globalizacja w stylu anglosaskim. Jej kryzys zapoczątkowany w 2007 roku, przeniesiony także do Unii Europejskiej, nie jest zjawiskiem neutralnym. Wzmocnił przekonanie o zmierzchu konsensu waszyngtońskiego, którego alternatywą po kryzysie azjatyckim z lat 1997-1998, zdaniem części badaczy, stał się „konsens pekiński”, atrakcyjny w wielu krajach Afryki, Azji i Ameryki Południowej.

Joshua Cooper Ramo - autor określenia „konsens pekiński” — twierdzi, że nowy chiński paradygmat rozwoju nie opiera się wyłącznie na ekonomii, lecz ma charakter geopolityczny. Konsens ten bazuje na rządach autorytarnych, ka-

\footnotetext{
12 Niektórzy ekonomiści uważają, że sukces reform od 1978 roku polegał na wprowadzeniu innowacji instytucjonalnych odbiegających od ortodoksyjnych zachodnich rekomendacji, co umożliwiało wejście w globalizację na warunkach korzystnych dla ChRL. Wśród najważniejszych z nich wskazywane jest między innymi uruchomienie aktywności produkcyjnej chłopów i prywatnej przedsiębiorczości we współpracy z władzami lokalnymi, stopniowe znoszenie barier handlowych $\mathrm{w}$ relacjach $\mathrm{z}$ zagranicą łączone $\mathrm{z}$ inwestowaniem $\mathrm{w}$ rodzime przedsiębiorstwa $\mathrm{w}$ celu przygotowania ich do konkurencji międzynarodowej, tworzenie specjalnych stref ekonomicznych pozyskujących inwestorów zagranicznych transferujących nowoczesne technologie do przemysłów eksportowych, ochrona rynku wewnętrznego w celu zachęcenia biznesu do inwestowania $\mathrm{w}$ dobra konsumpcyjne, słaba egzekucja praw własności intelektualnej obniżająca koszty imitowania nowoczesnych technologii zagranicznych, stymulowanie innowacyjnych centrów rozwoju przemysłowego, organizowane przez rząd szkolenie pracowników i kadry kierowniczej, konsolidowanie krajowych przedsiębiorstw i wspieranie powstawania nowoczesnych firm zdolnych do konkurencji na globalnych rynkach oraz utrzymywanie niskiego kursu waluty narodowej w celu subsydiowania przemysłów eksportowych (Rodrik 2011, s. 149-159).

$13 \mathrm{~W}$ ostatnich latach na skalę takich asymetrii zwrócily uwagę antysystemowe masowe protesty i ruchy społeczne w wielu krajach świata, począwszy od rewolucji w Tunezji i Egipcie, poprzez rewolucję w Islandii, indignadas w Hiszpanii i Occupy Wall Street w Stanach Zjednoczonych (Castells 2013).
} 
pitalizmie państwowym, reformach gospodarczych i rosnących innowacjach, a jego zasadą jest ochrona krajowego przemysłu, wzrost generowany przez eksport oraz intensywna akumulacja rezerw ${ }^{14}$. Spektakularne sukcesy ekonomiczne Chin i innych państw Azji Wschodniej po drugiej wojnie światowej wytworzyły nowe wyzwania poznawcze. Ich rozwój opierał się na połączeniu merkantylizmu (w uzyskiwaniu nadwyżek w bilansie płatniczym i protekcjonizmie) oraz ekonomii neoklasycznej w zakresie roli państwa w gospodarce. Wyróżniają się one równowagą między autonomią gospodarki narodowej a integracją międzynarodową oraz między państwem a rynkiem. W dyskusjach o Azji Wschodniej badacze porównujący rozwój tego regionu $z$ innymi obszarami geograficznymi świata odnotowują, że „teoria ogólna musi być w stanie objąć te [...] przypadki, których nie można nazwać marginalnymi” (Berger 1995, s. 221). Nawet jeśli przyjąć, że rozwój Chin od 1978 roku to przypadek wyjątkowy, nie można go traktować jako marginesu, zarówno ze względu na skalę zmian, jak i wielkość tego państwa - obszarem niemal równego Europie i o potencjale demograficznym zbliżonym do wszystkich krajów zachodnich łącznie. Dotychczas zmiany w Chinach nie zostały adekwatnie ujęte w ramach teorii rozwoju, a sukcesy reform gospodarczych w tym państwie postrzegane są przez główny nurt ekonomii jako anomalia, która jest trudna do wyjaśnienia w kategoriach teoretycznych (Qian 2003).

Sinolodzy podkreślają, że próby charakteryzowania rzeczywistości chińskiej za pomocą wypracowanych na Zachodzie kategorii nauk społecznych, opartych na odmiennych strukturach i instytucjach, budzą kontrowersje i nie dają dobrych rezultatów (np. Tomala 2001). Jednak casus Chin podważa uniwersalny charakter tych kategorii i wspiera tezę Wallersteina o potrzebie zwiększenia reprezentacji myśli społecznej tego kraju w światowej produkcji wiedzy. Tym bardziej że, zdaniem analityków, ze względu na jakościowe zmiany światowego porządku wchodzimy $\mathrm{w}$ fazę przejścia od koncentracji na kwestiach ekonomicznego rozwoju Chin, przez skupienie na kwestiach politycznych, do wielkiej zmiany, która niebawem „będzie dotyczyć sfery idei i ideologii” (Leonard 2008). Lektura Suna pozwala lepiej rozumieć historyczne źródła takich przemian, w tym krytycyzm przywódców Chin wobec zachodnich koncepcji globalnego rządzenia i ich asertywne akcentowanie mocarstwowej pozycji w świecie ${ }^{15}$. Zwłaszcza że polityka zagraniczna ChRL tradycyjnie jest reali-

\footnotetext{
14 Szerzej na temat porównań konsensu waszyngtońskiego i pekińskiego zob. Rickards 2014, s. $110-126$.

15 Przekonanie o wyższości Chińczyków nad innymi narodami stanowi azjatycki odpowiednik eurocentryzmu. Jest dziedzictwem konfucjanizmu i tradycji cesarstwa chińskiego uznawanego za depozytariusza uniwersalnej cywilizacji, której centrum stanowiło Państwo Środka. W końcu lat dziewięćdziesiątych XX wieku rosnąca rola Azji Wschodniej znalazła odzwierciedlenie ideologiczne w postaci koncepcji „wartości azjatyckich”, podkreślającej konieczność respektowania przez Zachód wartości i norm ukształtowanych przez wieki w tym regionie. Koncepcja ta nie zawiera ambicji narzucania takich wartości krajom nieazjatyckim (Gawlikowski 2004).
} 
zowana w ramach paradygmatu neorealistycznego kierującego się interesem narodowym, legitymizowanego patriotycznie lub nacjonalistycznie. Natomiast polityka państw zachodnich prowadzona jest głównie $\mathrm{w}$ ramach paradygmatu neoliberalnego opartego na wielości interesów, w którym państwo nie jest podmiotem autonomicznym (a często ważniejsze są inne preferencje, na przykład wielkiego biznesu). Z polskiej perspektywy warto zwłaszcza poznać chińską interpretację wydarzeń politycznych, przesłanki przekonania o szczególnej wartości kultury chińskiej, a także rozważania dotyczące poszukiwania własnego modelu rozwoju gospodarczego i demokracji.

W świetle następstw globalnego kryzysu kapitalizmu nowego znaczenia nabierają uwagi Suna dotyczące odmienności ustrojowych w różnych państwach i regionach świata. Przykładem mogą być podejmowane w ekonomii politycznej i socjologii gospodarczej badania dotyczące zróżnicowania kapitalizmu (varietes of capitalism, VoC). Wykazują one utrzymywanie się w świecie zachodnim i ewolucję odrębnych instytucjonalnie modeli kapitalizmu — anglosaskiego, skandynawskiego, południowoeuropejskiego i Europy kontynentalnej. Rozwijają się także badania nowych odmian kapitalizmu w posocjalistycznej Europie, w tym w Polsce, krajach dawnego Związku Radzieckiego oraz w Azji Wschodniej (Jasiecki 2013). Dowodzą one, że niemal wszystkie azjatyckie formy kapitalizmu - $z$ wyjątkiem Japonii - są zasadniczo odmienne od modeli zachodnich. Ich charakterystyki wymagają wykroczenia poza utrwalone $\mathrm{w}$ nauce ramy teoretyczne, wypracowane w zachodnim kontekście historycznym i kulturowym.

Porównania głównych gospodarek azjatyckich wyróżniły pięć modeli biznesowych: postsocjalistyczny, wysoko rozwiniętych miast, rozwijającej się Azji Południowej, wysoko rozwiniętej Azji Północnej i Japonii (Witt, Reading 2013) ${ }^{16}$. Politycznym oraz ideologicznym komponentem dyskusji o odmienności rozwoju gospodarczego w tym regionie świata są badania nad „kapitalizmem konfucjańskim", w którym szybkiej industrializacji towarzyszyło utrzymywanie się autorytarnych form rządzenia (Lee 2011). W przypadku ChRL taka odmiana organizacji politycznej państwa jest określana mianem „demokracji z chińską specyfiką". Zdaniem części badaczy, Chiny jako największa przeciwwaga neoliberalnego kapitalizmu mogą stać się zalążkiem alternatywnego projektu ustrojowego wykraczającego poza znane obecnie koncepcje polityczne i gospodarcze (Chołaj 2014). Nie rozstrzygając zasadności takich prognoz można jednak stwierdzić, że propagowane przez Sun Yat-sena rozpatrywanie patriotyzmu jako ważnego kapitału politycznego, gospodarczego i społecznego, wzmacnianie wewnętrznych potencjałów rozwoju państwa w warunkach dużych szoków zewnętrznych i wypracowywanie rozwiązań instytucjonalnych optymalnych dla własnego kraju, nie straciły wartości także współcześnie.

16 Zob. specjalny numer „Socio-Economic Review” z 2013 roku, poświęcony kapitalizmowi azjatyckiemu. 
Zmieniają się konteksty historyczne i formy organizacji społeczeństwa, ale problemy rozwoju są nadal aktualne.

\section{BIBLIOGRAFIA}

Berger Peter L.,1995, Rewolucja kapitalistyczna, tłum. Zygmunt Simbierowicz, Oficyna Naukowa, Warszawa.

Castells Manuel, 2013, Sieci oburzenia i nadziei. Ruchy społeczne $w$ dobie internetu, tłum. Olga Siara, Wydawnictwo Naukowe PWN, Warszawa.

Chan Kenneth Ka-Lok, 1996, Państwo autorytarne a tajwański cud gospodarczy, „Studia Polityczne”, nr 5.

Chang Jung, 2003, Dzikie tabędzie: trzy córy Chin, tłum. Bożena Umińska, Albatros, Warszawa.

Chołaj Henryk, 2014, Kapitalizm konfucjański. Chińskie reformy ekonomiczne a globalizacja, Poltex, Warszawa.

Gawlikowski Krzysztof, 2004, Procesy okcydentalizacji Chin oraz innych krajów Azji Wschodniej $i$ ich stosunek do cywilizacji zachodniej, w: Adam W. Jelonek (red.), Wietnamczycy: systemy wartości, stereotypy Zachodu, Scholar, Warszawa.

Gawlikowski Krzysztof, 2012, Dzieje Cesarstwa, w: Historia Chińczyków. Pomocnik historyczny Polityki.

Góralczyk Bogdan, 2013, Sun Yat-sen. Misjonarz rewolucji, Rambler, Warszawa.

Gray John, 2001, Po liberalizmie. Eseje wybrane, tłum. Paweł Maciejko, Piotr Rymarczyk, Fundacja Aletheia, Warszawa.

Jasiecki Krzysztof, 2013, Kapitalizm po polsku. Między modernizacja a peryferiami Unii Europejskiej, IFiS PAN, Warszawa.

Lee Haesung, 2011, Kapitalizm konfucjański. Koreańska droga rozwoju, Wydawnictwo Adam Marszałek, Toruń.

Legrand Catherine, Legrand Jacques (red.), 2000, Mao Zedong, tłum. zbiorowe, Bellona, Warszawa. Leonard Mark, 2008, Najważniejsze sa Chiny, „Europa. Tygodnik Idei”, 7 czerwca.

O'Neil Jim, 2013, Mapa wzrostu. Szanse gospodarcze dla państw grupy BRICs, Studio Emka, Warszawa.

$\mathrm{Pu}$ Yi, 1988, Bytem ostatnim cesarzem Chin, tłum. Jolanta Mach, Wydawnictwo Łódzkie, Łódź.

Qian Yingyi, 2003, How Reform Worked in China, w: Dani Rodrik (red.), In Search of Prosperity, Princeton University Press, Princeton.

Rickards James, 2015, Śmierć pieniądza. Nadchodzacy upadek międzynarodowego systemu walutowego, tłum. Michał Lipa, Helion, Gliwice.

Rodrik Dani, 2011, The Globalization Paradox. Why Global Markets, States, and Democracy Can't Coexist, Oxford University Press, Oxford.

Rowiński Jan, Jakubiec Wojciech, 2006, System konstytucyjny Chińskiej Republiki Ludowej, Wydawnictwo Sejmowe, Warszawa.

Sun Yat-sen, 2014, Trzy zasady ludu, tłum. Agnieszka Łobacz, Wydawnictwo Akademickie Sedno-Szkoła Wyższa Psychologii Społecznej, Warszawa.

Tomala Karin (red.), 2001, Chiny. Przemiany państwa i spoleczeństwa w okresie reform 1978-2000, ISP PAN-Trio, Warszawa.

Witt A. Michael, Reading Gordon, 2013, Asian Business Systems: Institutional Comparison, Clusters and Implications for Varieties of Capitalism and Business Systems Theory, „Socio-Economic Review”, t. 11 , s. 265-300.

Wallerstein Immanuel, 2004, Statement, w: Conference Program. Social Change in the Age of Globalization. $36^{\text {th }}$ World Congress, Institute of Sociology CASS, Beijing 7-11 lipca.

Yu-Lan Fung, 1991, Selected Philosophical Writings, Foreign Languages Press, Beijing. 


\section{WHY IS IT WORTHWHILE TO READ SUN YAT-SEN? \\ THE ADVANTAGES OF READING THE WORK OF THE MODERN CHINA'S 'SPIRITUAL FATHER'}

\section{Sum mary}

The author describes the political concepts of Sun Yat-sen, leader of the Kuomintang party, whose views largely shaped the thinking of the Chinese elite about the modernization of the state and China's place in the world. These concepts are considered in relation to contemporary interpretations of the systemic and economic development of the People's Republic of China, the otherness of the 'Confucian capitalism' of East Asia, the limitations of the western concept of global government, and the crisis of neoliberal globalization.

\section{Key words/słowa kluczowe}

political concepts of Sun Yat-sen / koncepcje polityczne Sun Yat-sena; Chinese version of modernization / chińska wersja modernizacji; Confucian capitalism / kapitalizm konfucjański 